\title{
Peat soil mass stabilization using geopolymeric hybrid material in early age
}

\author{
Gunawan Wibisono ${ }^{1 *}$, Erwin ${ }^{1}$, Alfian Kamaldi $^{1}$, Monita Olivia ${ }^{1}$ \\ ${ }^{1}$ Department of Civil Engineering, Universitas Riau, Pekanbaru, Indonesia
}

\begin{abstract}
Peat is an organic soil, highly compressible and has high water content. The soil needs to be stabilized chemically by incorporating binders such as cement and lime into the soil that will change the properties and soil strength. However, stabilization using cement solely is not recommended since the organic acid in peat soil could delay cement hydration process. Furthermore, mass stabilization using pozzolanic material also could improve strength development of peat soil. In this research, the pozzolanic material in the form of geopolymer hybrid or geopolymer with the addition of Ordinary Portland Cement was investigated. Geopolymer was produced by activating fly ash with a combination of $\mathrm{NaOH}$ and sodium silicate. OPC addition improves initial strength and assists geopolymerization at ambient temperature. Variables studied were binder content and a percentage of OPC, and percentage of fly ash. Unconfined Compressive Stress (UCS) at 7 days was measured for all specimens. Mass stabilization using fly ash geopolymer hybrid could improve strength development of peat soil.
\end{abstract}

\section{Introduction}

Construction of infrastructure such as highway in peat ground is inevitable due to demand of accessibility from different places. Peat soil is considered problematic because it is soft and has high organic content. The soil needs to be treated to improve soil bearing capacity and reduce potential differential settlements damage of the ground. Stabilization is considered an alternative to enhance the peat soil characteristics in construction rather than cut to reduce the amount of peat soil in the field. Mass stabilization is a type of stabilization that mix the binder with soil in a massive volume to homogenize the soil [1]. Using a sufficient amount of binder could help to improve strength gain by producing a stronger network of peat.

Highly water and organic content of peat are two major issues in soil improvement. Previous studies highlighted that peat with high organic content is difficult since the reaction between organic matter and binder results in low strength development [2]. Organic matter in peat contains humic acid and various organic acids such as fulvic and humin that tend to delay the formation of hydration product that can delay stabilization process. Stabilization using a sole binder such as Ordinary Portland Cement (OPC) is not

*Corresponding author: g.wibisono@eng.unri.ac.id 
recommended due to the high affinity of acid and organic matter in peat with calcium [3, 4]. Organic content in peat is known to delay hydration and secondary pozzolanic reactions of peat stabilized with OPC.

Binder used in mass stabilization is usually a mix of various materials with OPC. Highly pozzolanic materials rich in silicate are potential to be used in the mix. From previous studies, binder mixed with silicate materials strengthen by enhancing pozzolanic reaction $[5,6]$. In the next stage, geopolymer has been studied as an alternative as a stabilizer of soft soil. Compact and homogeneous microstructures were observed after soil stabilized with metakaolin geopolymer in one study [7]. Metakaolin geopolymer has potential characteristics to be used as a stabilizer for peat ground. It could provide high early strength, lower shrinkage and comparable strength than the ordinary binder.

Fly ash as coal power station industrial waste is used as the primary material for geopolymer. However, geopolymer activated with sodium hydroxide and sodium silicate cannot be hardened very quickly due to its high silicate content without high temperature. Since curing is an issue of fly ash geopolymer, then an additional curing agent such as Ordinary Portland Cement was added to accelerate geopolymer product formation in concrete [8]. In this research, geopolymer hybrid or fly ash geopolymer with OPC as curing agent with different binder amount was investigated. Unconfined compressive strength (UCS) at 7 days as a measure of the effectiveness of strength gain of stabilized peat was analyzed.

\section{Materials and methods}

The soil was collected from a site in Rimbo Panjang, Kampar Regency, Riau Province. The properties of the soil are presented in Table 1.

Table 1. Basic properties of peat from Rimbo Panjang.

\begin{tabular}{|c|c|}
\hline Basic soil property & Values \\
\hline Natural moisture content (\%) & 308.8 \\
\hline Specific gravity & 1.21 \\
\hline Fiber content (\%) & 4.54 \\
\hline Ash content (\%) & 4.64 \\
\hline Organic content (\%) & 95.36 \\
\hline $\begin{array}{c}\text { Peat soil classification } \\
\text { (ASTM D4427-84-1989) }\end{array}$ & $\begin{array}{c}\text { Low ash, sapric moderately } \\
\text { absorbent }\end{array}$ \\
\hline
\end{tabular}

It can be seen that peat has high organic content with low fibre content. The peat soil in Rimbo Panjang is classified as sapric because it has low fibre content (less than 17\%). This soil has a high groundwater table, and it is widespread in Rimbo Panjang regency.

Fly ash from Ombilin, West Sumatra was used as geopolymer raw material for soil stabiliser. Ordinary Portland Cement (OPC) was added to improve soil properties and curing of geopolymer. The chemical composition of fly ash and OPC is displayed in Table 2.

Fly ash geopolymer hybrid as soil stabiliser used alkaline activator solution consists of sodium hydroxide, sodium silicate, water and some amount of OPC. Sodium hydroxide $10 \mathrm{M}$ used was approximately $8 \%$ from peat soil volume. Sodium silicate included was 
$50 \%$ of the amount of total $\mathrm{NaOH}$. Water was added to fulfil peat field moisture content, i.e. $318.8 \%$.

Table 2. Chemical composition of Ordinary Portland Cement and fly ash.

\begin{tabular}{|c|c|c|}
\hline Chemical composition & $\begin{array}{l}\text { Ordinary Portland } \\
\text { Cement }(\%)\end{array}$ & Fly $\operatorname{ash}(\%)$ \\
\hline Silicone Dioxide $\left(\mathrm{SiO}_{2}\right)$ & 20.92 & 59.25 \\
\hline Aluminium Trioxide $\left(\mathrm{Al}_{2} \mathrm{O}_{3}\right)$ & 5.49 & 29.25 \\
\hline Iron Trioxide $\left(\mathrm{Fe}_{2} \mathrm{O}_{3}\right)$ & 3.78 & 5.45 \\
\hline Titanium Dioxide $\left(\mathrm{TiO}_{2}\right)$ & - & 0.83 \\
\hline Calcium Oxide $(\mathrm{CaO})$ & 65.21 & 1.54 \\
\hline Magnesium Oxide (MgO) & - & 0.31 \\
\hline Potassium Oxide $\left(\mathrm{K}_{2} \mathrm{O}\right)$ & - & 2.23 \\
\hline Sodium Oxide $\left(\mathrm{Na}_{2} \mathrm{O}\right)$ & - & 0.68 \\
\hline Phosphorus Pentoxide $\left(\mathrm{P}_{2} \mathrm{O}_{5}\right)$ & - & 0.04 \\
\hline Sulphur Trioxide $\left(\mathrm{SO}_{3}\right)$ & - & 0.29 \\
\hline Manganese Dioxide $\left(\mathrm{MnO}_{2}\right)$ & - & 0.01 \\
\hline Moisture content $(\%)$ & - & 0.25 \\
\hline Loss On Ignition (LOI) (\%) & - & 18.89 \\
\hline
\end{tabular}

Table 3. Composition of soil specimen.

\begin{tabular}{|c|c|c|c|c|c|c|c|}
\hline \multirow[b]{2}{*}{ Mixes } & \multirow{2}{*}{$\begin{array}{c}\text { Binder } \\
\text { quantities } \\
\left(\mathbf{k g} / \mathbf{m}^{\mathbf{3}}\right)\end{array}$} & \multirow[b]{2}{*}{ Peat } & \multicolumn{5}{|c|}{ Binder (kg) } \\
\hline & & & OPC & $\begin{array}{l}\text { Fly } \\
\text { ash }\end{array}$ & $\begin{array}{c}\mathrm{NaOH} \\
10 \mathrm{M}\end{array}$ & $\mathrm{Na}_{2} \mathrm{SiO}_{3}$ & Water \\
\hline Peat & 0 & 233.66 & 0 & 0 & 9.35 & 18.69 & 721.54 \\
\hline Peat+GP75_OPC25 & 200 & 174.75 & 14.73 & 44.18 & 6.99 & 18.69 & 539.64 \\
\hline Peat+GP50_OPC50 & 200 & 174.75 & 29.45 & 29.45 & 6.99 & 18.69 & 539.64 \\
\hline Peat+GP25_OPC75 & 200 & 174.75 & 44.18 & 14.73 & 6.99 & 18.69 & 539.64 \\
\hline Peat+GP75_OPC25 & 250 & 160.03 & 18.41 & 55.22 & 6.40 & 18.69 & 494.16 \\
\hline Peat+GP50_OPC50 & 250 & 160.03 & 36.82 & 36.82 & 6.40 & 18.69 & 494.16 \\
\hline Peat+GP25_OPC75 & 250 & 160.03 & 55.22 & 18.41 & 6.40 & 18.69 & 494.16 \\
\hline
\end{tabular}

Specimens were prepared by drying the peat soil in ambient temperature. Then the peat soil was mixed with the fly ash geopolymer. The OPC in a range of $25-75 \%$ by binder 
weight was added to the mixture. The mixture was blended uniformly then specimens were cast into the mould and tamped in four layers in a plastic tube. Samples were placed vertically in a wooden rack. Unconfined compression tests were taken after curing about seven days. The test is following ASTM D 2166-85. Mix composition consists of two binder quantities, i.e. 200 and $250 \mathrm{~kg} / \mathrm{m}^{3}$, respectively. A detailed mix composition could be seen in Table 3 .

A cylindrical soil specimen of $50 \mathrm{~mm}$ diameter and $100 \mathrm{~mm}$ height is used as unconfined compressive strength sample. The axial load is applied vertically until the constant rate of strain is $1.5 \mathrm{~mm} / \mathrm{min}$. The stress is measured at peak stress of the soil stress-strain curve using the unconfined compression test load frame.

\section{Results and discussion}

Fig. 1 shows the Unconfined Compressive Stress-vertical strain of peat specimens at binder dosage of $200 \mathrm{~kg} / \mathrm{m}^{3}$ at early age. Generally, there is an increase in all specimens using geopolymer hybrid as binders compared to peat soil without additional binder. The highest strength achieved by peat stabilised using $25 \%$ geopolymer and $75 \%$ OPC as a binder. The specimen produced a compressive strength of $73.47 \mathrm{kPa}$, which was high for soft soil. The other binders, i.e. 75\% geopolymer and 25\% OPC (GP75_OPC25) and 50\% geopolymer and 50\% OPC (GP50_OPC50) yielded strength of $54.57 \mathrm{kPa}$ and $51.33 \mathrm{kPa}$, respectively.

At a binder dosage of $200 \mathrm{~kg} / \mathrm{m}^{3}$, the fly ash geopolymer hybrid $(25 \%$ and $75 \%)$ provides enough aluminosilicate product to neutralize the organic acid; thus high early strength could be achieved. Geopolymer is known to product aluminosilicate that has different network than the OPC cement hydration product. However, there was a lower strength development on the geopolymer hybrid (50\%) compared to others with a decrease in strength. The amount of binder that was not sufficient to reduce the adverse effect of organic in peat thus could reduce the strength gain [2].

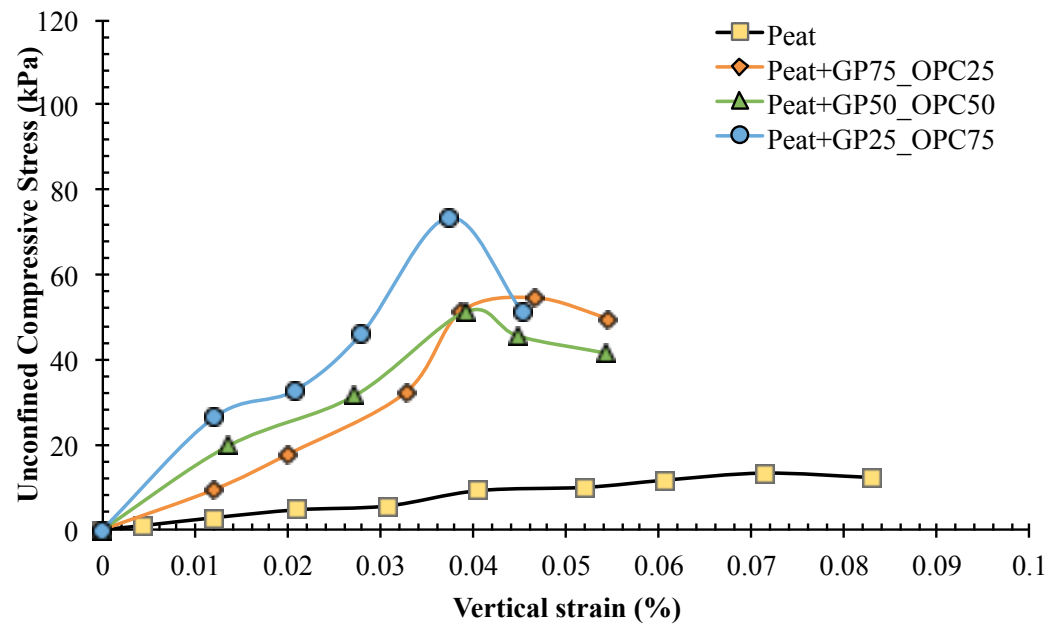

Fig. 1. Unconfined Compressive Stress-Vertical strain relationship of peat specimens using geopolymer and OPC as soil stabiliser at binder dosage $200 \mathrm{~kg} / \mathrm{m}^{3}$.

Unconfined compressive strength values of stabilised peat soil using geopolymer and OPC at binder dosage of $300 \mathrm{~kg} / \mathrm{m}^{3}$ could be seen in Fig. 2. The strength development was higher in early age than peat stabilised with a binder of $200 \mathrm{~kg} / \mathrm{m}^{3}$. This is because the 
amount of binder is sufficient to promote the early strength of stabilised peat. The highest confined strength of $97.06 \mathrm{kPa}$ was obtained by peat with $25 \%$ geopolymer and $75 \%$ OPC. OPC is effective to neutralize organic content of peat could be the reason for this behaviour. A similar finding was also reported by the previous author [5] since there are two causes of strength improvements by the cement of stabilised peat, that is, firstly, production of calcium silicate hydrate to bind the soil particles. Secondly, the inclusion of silicate material could improve the packing density of stabilized peat.

In general, there was a similar trend of strength development of all mixes compared to peat without any stabiliser. However, peat mixture with $50 \%$ geopolymer and $50 \%$ OPC has the strength of $53.50 \mathrm{kPa}$ and much lower than peat with $75 \%$ geopolymer and $25 \%$ OPC. This could be the most effective stabiliser mix since the quantity of binder added to exceed the threshold values to improve strength gain due to an increase of load-bearing skeleton in the soil. Stabilisation could be ineffective due to the amount of binder added to the soil that cannot reach the threshold strength development skeleton [2]. From this research, geopolymer hybrid with a composition of $75 \%$ geopolymer and $25 \%$ OPC at dosage $250 \mathrm{~kg} / \mathrm{m}^{3}$ could be seen as potential material for stabilization of peat soil.

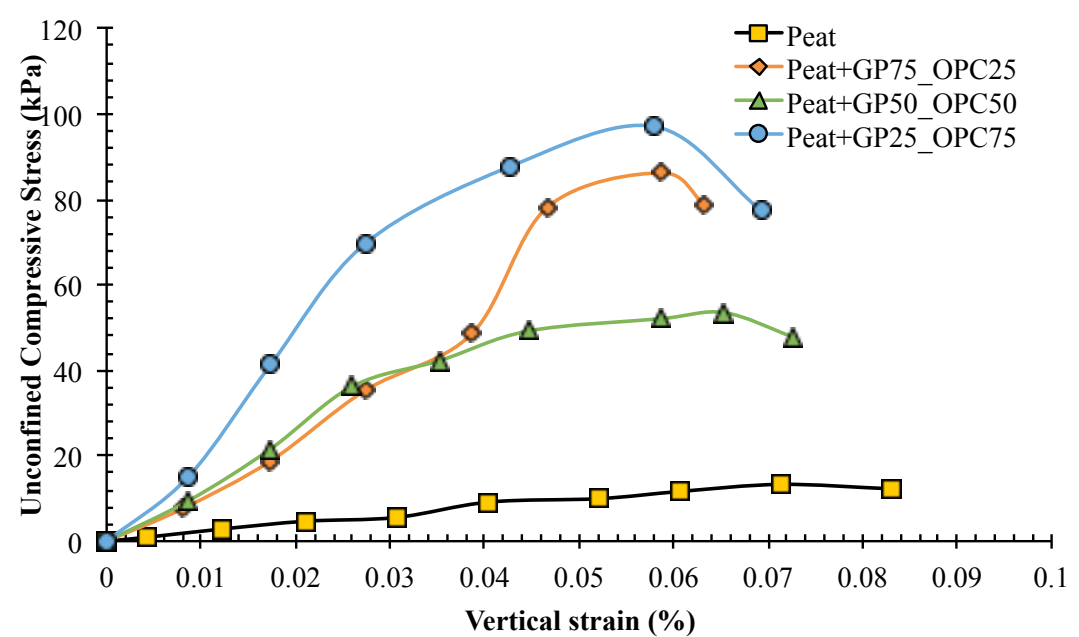

Fig. 2. Unconfined Compressive Stress-Vertical strain relationship of peat specimens using geopolymer and OPC as soil stabiliser at binder dosage $250 \mathrm{~kg} / \mathrm{m}^{3}$.

Mass stabilization of peat soil using additional silicate material such as geopolymer hybrid is recommended since it creates a formation of calcium silicate hydrates to improve high early strength gain [6]. Silicate could react to resist organic acid compared to use OPC as a single binder to stabilise the peat. Another important parameter is a binder dosage because the strength increases with binder dosage because the amount of silicate in peat has also increased. Fly ash geopolymer hybrid could improve the peat soil unconfined stress by providing the amount of silicate and increase the strength development of peat soil

\section{Conclusions}

Fly ash geopolymer hybrid was used as soil stabiliser for peat. Two types of binder consist of $200 \mathrm{~kg} / \mathrm{m}^{3}$, and $250 \mathrm{~kg} / \mathrm{m}^{3}$ were investigated. Based on the study it can be concluded that the fly ash geopolymer hybrid improves strength development of peat compared to peat without additional binder. At the same dosage of binder and curing duration, fly ash 
geopolymer hybrid with $25 \%$ geopolymer and $75 \%$ OPC gives the highest strength than others mixes due to high resistance from organic acid between the soil particles in early age or at 7 days. The amount of binder influenced the strength gain because of the sufficient amount of fly ash geopolymer hybrid that can affect the formation of stabilized peat structure that can improve the soil strength. In conclusion, the mass stabilization using fly ash geopolymer hybrid could improve the unconfined compressive stress of peat soil.

Authors acknowledged the support/funding from Penelitian Unggulan Perguruan Tinggi 2018 PNBP LPPM Universitas Riau Contract no. 651/UN.19.5.1.3/PP/2018.

\section{References}

1. M. Sha'abani, B. Kalantari, ARPN J. of Sci. and Tech. 2 (2012)

2. W.L. Sing, R. Hashim, F.H. Ali, 2009. Australian J. of Basic and Applied Sci. 3 (2009)

3. S. Kazemian, S. Soil Mech. and Foundation Eng. 52 (2015)

4. H. Jafer, W. Atherton, M. Sadique, F. Ruddock, E. Loffil, 2018. Appl. Clay Sci. 152 (2018)

5. S. Kazemian, A. Prasad, B.B.K. Huat, T.A. Mohammad, F.N.A. Aziz, J. Chinese Inst. of Eng. 36 (2013)

6. B.B.K. Huat, S. Kazemian, W.L. Kuang, 2011. EJGE 16 (2011)

7. M. Zhang, H. Guo, T. El-Korchi, G. Zhang, M. Tao, 2013. Con. Build. Mat. 47 (2013)

8. M. Askarian, Z. Tao, G. Adam, B. Samali, 2018. Con. Build. Mat. 186 (2018) 